5.

\title{
DRAMATURGIJA SLOBODE I SMRTI \\ ILI O LJESTVAMA JAKOVLJEVIM \\ VLADANA DESNICE \\ U SVETLU SARTROVE TEORIJE \\ POZORIŠTA SITUACIJA
}

\section{Aleksandra Kuzmić}

UDK: 821.163.42-2Desnica, V.

Izvorni znanstveni članak

Sažetak: U radu se ispituju veze Desničinih Ljestava Jakovljevih sa pozorištem situacija, čije je osnove postavio i razradio Žan-Pol Sartr u teorijskim spisima o teatru. Tema je istraživana komparatistički, uz korišćenje odgovarajućih metoda teorijske dramaturgije i istorije pozorišta. U središtu Ljestava Jakovljevih je čovek u ratnom vremenu, pred kojim je životno značajno ali i univerzalno pitanje odgovornosti pojedinca u dramatičnim okolnostima, pitanje najtešnje povezano sa ličnim moralom i odnosom prema slobodi i smrti. A upravo ove elemente autor postavlja u osnove ideološkog, tematskog i dramaturškog tlocrta svog dramskog prvenca, uvodeći ga time u žanrovske okvire koje Sartr označava kao obnovu klasičnog tragičkog diskursa u novom vremenu, jer junak strada svojom krivicom, u sudaru sa istorijskim datostima. Desnica se, gradeći lik Jakova Pećine, opredeljuje da ovog junaka predstavi kao karakter u nastajanju, da predoči trenutak izbora, slobodnu odluku koja angažuje moral $i$ čitav jedan život. Dramski sukobi utemeljeni su na sukobima aktuelnih prava vezanih za svakodnevni život, te se stoga ovo delo, premda su ga i autor i kritičari posmatrali ili kao psihološku, ili kao realističku, odnosno realističko-naturalističku dramu, pokazuje kao značajno i čvrsto oslonjeno na temeljne poetičke odrednice pozorišta situacija. Ljestve Jakovljeve se, zahvaljujući načinu na koji se u delu, eksplicitno i implicitno, ispoljavaju sloboda i smrt, velikim delom uklapaju u tadašnji novatorski manir svojstven francuskim autorima, iako ga ni Vladan Desnica ni ondašnji pozorištnici ne čitaju u tom dramskom ključu. ${ }^{1}$

Ključne reči: Ljestve Jakovljeve, pozorište situacija, sloboda, smrt, sukob prava, izbor, mit

\section{PitAnje ŽAnRA}

『] napisima koji su osvanuli u beogradskoj štampi februara hiljadu devetsto šezdeset prve godine, povodom premijere Ljestava Jakovljevih Vladana Desnice, pozorišni kritičari ovaj dramski tekst pominju isključivo kao psihološku, realističku, odnosno realistič-

$\overline{1}$ Rad je nastao u okviru naučnog projekta Instituta za književnost i umetnost iz Beograda ON 178008 Srpska književnost u evropskom kulturnom prostoru, koji finansira Ministarstvo prosvete, nauke i tehnološkog razvoja Republike Srbije. 
ko-naturalističku dramu, pisanu pod snažnim uticajem Krležine dramaturgije. ${ }^{2}$ Istovremeno, Ljestvama Jakovljevim odriču bilo kakvu vezu sa „savremenim, novatorskim manirom svojstvenim francuskim autorima", 3 što se odnosi prvenstveno na Sartra, Kamija, Anuja i Koktoa te na obeležja njihovih dramskih dela. Za ovo jednostrano određenje nisu zaslužni samo tadašnji teatarski znalci - podstakao ga je i autor komada. Naime, u članku kojim se u Politici najavljuje premijera, Desnica kaže:

Ljestve Jakovljeve je psihološka drama u kojoj nema velikih spoljnih zbivanja. To su intimna, unutrašnja raspinjanja, puna samoosuđivanja glavnih junaka. Kada to kažem, mislim da nije bitno šta se sve zapravo u životu događalo ili moglo događati. Nije u prvom planu njihova stvarna, životno verodostojna sudbina. Zamisao je bila da se prikažu složeni, najdublji intimni porivi ljudske ličnosti koji u vremenu ratnog stradanja dobijaju svoj poseban intenzitet i oblik. ${ }^{4}$

\section{Tomislav Tanhofer, reditelj predstave, ${ }^{5}$ intervjuisan istim povodom, izdvojio je}

(...) briljantna i veoma tanana psihološka samoispitivanja junaka puna (...) dramskih valera, koji pružaju mogućnost stvaranja veoma intenzivnih scenskih zapleta u kojima dominira, pored sve košmarske mističnosti, veliki humanistički ideal pisca u kome on nalazi izlaz i rešenje za sva intimna preživljavanja i sukobe. ${ }^{6}$

Zašto se u vezi sa Desničinim Ljestvama Jakovljevim uopšte bavim pitanjem književnog odnosno dramskog žanra, koje bi se u dvadeset prvom veku, posle radova Fraja, Pavisa, Lemana, Gerde Pošman, Sarazaka i niza drugih teoretičara pozorišta i drame, moglo smatrati itekako prevaziđenim? Odgovor bi bio da postojeća, uvrežena oznaka dramske vrste sužava polje komparativnog tumačenja ovoga komada i vodi prenebregavanju značajnih uvida koji se tiču uzajamnosti Desničinog dela i evropske dramske produkcije nastale tokom i posle Drugog svetskog rata. Uz to, da bi se utvrdila saglasja, uticaji i dometi, neophodno je da se Ljestve Jakovljeve pogledaju okom nezamagljenim preuskim okvirom realističke, psihološke, ili naturalističke drame, jer će to omogućiti da se ne zapostave obeležja koja ovo delo čine ne samo bliskim pozorištu situacija već pokazuju da je značajno oslonjeno na njegove idejne postavke. Govoreći u prilog toj zasnovanosti potcrtala bih Desničine reči prema kojima „u prvom planu“ nije „stvarna, životno verodostojna sudbina“, nego „porivi ljudske ličnosti“

2 Reč je o četiri teksta čiji su autori Eli Finci („Интелектуанне распр““, Политика, br. 17019, 18. 2. 1961., 10), Slobodan Selenić („ВАадан Аесница: Һестве Јаковьеве“, Борба, br. 40, 18. 2. 1961., 7), Miloslav Mirković („Ljestve Jakovljeve“, Mladost, 6/1961., br. 228, 7) i Vladimir Stamenković („Sumnja u intelektualnu akciju“, Književne novine, 12/1961., br. 139, 7).

3 С. СЕленит, „ВАадан Аесница: Фестве Јаковьеве“, 7.

4 И[ванка] Б[Ешевић], „, Вестве Јаковљеве ВАадана Аеснице“, Политика (БеограА), br. 17017, 16. 2. 1961., 11.

5 Čini mi se neophodnim da naglasim kako je predstavu režirao Tomislav Tanhofer, o čemu svedoče kako plakat predstave, tako i najava premijere, te kritike objavljene u ondašnjoj štampi. Naime, u nekim se veoma analitičnim tekstovima o Desničinim Ljestvama Jakovljevim ponavlja jedna te ista pogreška: kao reditelj ovog komada u Jugoslovenskom dramskom pozorištu navodi se Nikola Tanhofer. Videti: Helena Peričić „Izdaja / krivnja / ideologija u Desničinoj drami Ljestve Jakovljeve", Tekst, izvedba, odjek. Trinaest studija iz hrvatske i inozemne dramske književnosti, Zagreb 2008., 121-135; Ista, „Jezik ideologije i ideologija jezika u Desničinoj drami Ljestve Jakovljeve“, Desničini susreti 2010. Zbornik radova (ur. Drago Roksandić i Ivana Cvijović Javorina), Zagreb 2011., 50; Jadranka BRnčić, „Problem etičkog angažmana u Desničinim Ljestvama Jakovljevim", Intelektualci i rat 1939. - 1947. Zbornik radova s medunarodnog skupa Desničini susreti 2012. (ur. Drago Roksandić i Ivana Cvijović Javorina), sv. 1, Zagreb 2013., 46.

6 И. БЕшевит, „Дестве Јаковљеве ВАадана Аеснице“, 11. 
u „vremenu ratnog stradanja“, i Tanhoferovo izdvajanje „velikog humanističkog ideala pisca“, u kojem autor pronalazi „izlaz i rešenje za sva intimna preživljavanja i sukobe“. I jedno i drugo upućuju na udaljavanje od realističke odnosno naturalističke poetike i iskorak u, kako ga imenuje Jovan Hristić, Sartrovo „retoričko pozorište svesnih odluka“7
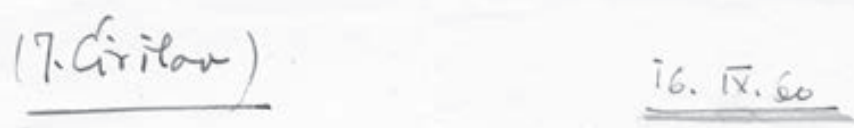

Poxtovan1 aruže Desnica, (Zagrcele)

Neobiðno m1 je drago ăto Vas mogu obavestiti da je rad na Vařen dramskon delu "Ljestve Jakovljeve" poð̌eo proăle nedelje 1 - poale jednog kraceg prekida zoog bolest1 Milivoja Z1vanoví́a - nastavio ae juð̌e pod rukovodstvom Tom1slava Tanhofera. Jloge su podeljene nar̉im najtminentnjjIm clanovima: Milivoju Zivanovibu, Marij1 Crnobor1, Viktoru Starčló, Nad1 R1zn16, Jož1 Rut16u, Dubravk1 Per16 1 glumo1ma nă̌e najmladje generaclje za woge \$rojevaca. Scenografiju smo poverill veoma talentovanom mladom scenografu $1 \mathrm{z}$ Priatinskog pozoriăta, koji Je prořle sezone bio narodito zapažen u Beogradu prilikom svog gostovanja sa scenografskim nacrtima za Soovu komed1ju "N1kad se ne sna", a ove sezone dao je scenograf1ju za pretstava "Stenica" od "ajakovakog koju Miroslav Belovió režira za naĕu Malu scenu. Kod njega postoj1 sreban spoj talents za 11 kovne valere 1 veliko praktiono pozoríno 1skustvo, koje 6e bit1 veoma ră̌no sa $V_{a}$ ăe delo.

U žlj1 da budete upoznat1 sa tokon rada 1 da blate stupill u kontakt aa narim ansamblom 1 glumol b1l1 u mogucnost1

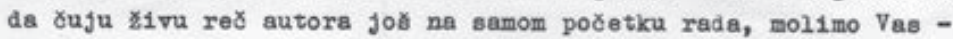
ako Vam je to ikako moguóno + da dodjete u Beograd u utorak, 20 septembra na dva-tr1 dans ( samo se po seb1 razume da Vam Pozorírte plaba put 1 dnevnice). U to vreme dod1 ce u Beograd 1 scenogral retar Pario pa bete prisustvovat1 1 prv1m razgovorima reditelja o scenografskom oblikovanju tă̌e drame. Ansambl, koj1 je pokazeo velikin interes 1 odủevljenje za Văe delo ved prilikon prvog ditanja, s nestrpljenjez ocekuje $v_{a}$ dolazak. Javite telegranon kad ot1rete rad1 obebbedjenja sobe u hotelu.

Sxdačno Vaa pozdravlja,

Beograd, 16.IX.1960 god.
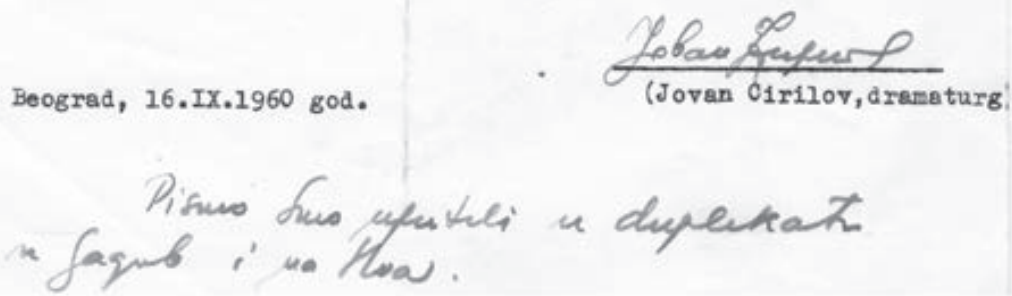

Sl. 1. Pismo dramaturga Jovana Ćirilova Vladanu Desnici

7 Jovan Hristić, „Beketovo pozorje ljudskog života“, Studije o drami, Beograd 1986., 134. 
Argumentovano poredeći tematske, idejne i dramaturške osobenosti Desničinog komada sa premisama Sartrove teorijske dramaturgije, nastojaću da izbegnem zamke danas tako čestog naučnog relativizma, i pokažem po čemu su, i u kojoj meri, Ljestve Jakovljeve saobražene tragičkom diskursu svojstvenom pozorištu situacija.

\section{SARTROVA TEORIJSKA DRAMATURGIJA -}

\section{ZA POZORIŠTE SITUACIJA}

Pošto Sartr osmišljava celovit pogled na pozorišnu praksu, Jovan Hristić s razlogom navodi da se „Sartrovi napisi o pozorištu“ mogu „po ozbiljnosti osnovnih misli (...) meriti ako ne s Brehtovom teorijom epskog teatra, a ono sigurno sa onim što je Strindberg mislio i pisao o pozorištu“. ${ }^{8}$ Osnovu „tog strogog, moralnog, mitskog i ritualnog pozorišta iz kojeg su nastali pozorišni komadi u Parizu tokom okupacije i neposredno posle rata" čini mreža čvrsto uvezanih i jasno definisanih ideja i pojmova poput slobode, opšte situacije, sukoba prava, smrti, karaktera u nastajanju, zajedništva gledalaca, pozorišta kao kolektivnog religioznog fenomena. Premda je ideja slobode zasnovana u autonomiji volje i njome uslovljenom biranju stvarnosti jedan od oslonaca Sartrove egzistencijalističke filozofije i književnog stvaralaštva, opredelila sam se da u ovom članku ostanem pri nevelikom broju tekstova ${ }^{10}$ koji se najdirektnije odnose na pozorište. Reč je o četiri relevantne teatrološke rasprave: $Z a$ pozorište situacija, ${ }^{11}$ Dramski stil,${ }^{12}$ Stvoriti mitove ${ }^{113}$ i Epsko i dramsko pozorište. ${ }^{14} \mathrm{U}$ radu je, kao teorijska osnova za bolje razumevanje pozorišta situacija, korišćen i intervju koji je Žan-Pol Sartr 1961. godine dao Kenetu Tajnanu. ${ }^{15}$

Iščitavanje teorijskih premisa Sartrovog pozorišnog organona nameće - što nije neočekivano - izvesna poređenja s Aristotelovim viđenjem tragedije, uprkos tome što francuski filozof i pisac tvrdi da on i oni u čije ime piše ne žele obnavljanje tragedije, niti stvaraju filozofske komade. Istovremeno, Sartr ne poriče „da ima nešto istine u tim etiketama“. ${ }^{16}$ Ako antička tragedija odražava antičko shvatanje čoveka, moglo bi se sa mnogo razloga pretpostaviti da pozorište situacija odražava shvatanje čoveka svojstveno generaciji mladih

\footnotetext{
8 Isto, 115.

9 Žan-Pol SARTr, „Stvoriti mitove“, Drame. Tekstovi o pozorištu, Beograd 1981., 404.

10 Svi tekstovi na koje se pozivam objavljeni su u prevodu Mirjane Miočinović u knjizi Žan-Pol SARTr, Drame. Tekstovi o pozorištu (= Izabrana dela, knj. 5), Beograd 1981. Posredi je izbor iz obimne knjige Un théâtre de situations (Gallimard, Paris 1973), u kojoj su sabrani brojni Sartrovi napisi, predavanja i intervjui vezani za pozorište i dramska dela.

11 „Tekst objavljen u La Rue, br. 12, novembar 1947.“ Ž.-P. SARTr, Drame. Tekstovi o pozorištu, 390.

12 „Tekst je prvi put objavljen u knjizi Un théâtre de situations, a na osnovu neredigovanog Sartrovog predavanja održanog 10. juna 1944. po želji Žana Vilara, koji je organizovao čitav niz predavanja-rasprava o pozorištu." Ž.-P. SARTR, Drame. Tekstovi o pozorištu, 398.

13 „Predavanje koje je Sartr održao u Njujorku godine 1946. objavljeno je prvi put u američkom časopisu Theatre Arts (Vol. XXX, 6, 1946) pod naslovom Forgers of Myths: The Young Playwrights of France. U Francuskoj je tekst štampan prvi put u knjizi Un théatre de situations, Paris, Gall., 1973, str. 55-67." Ž.-P. SARTr, Drame. Tekstovi o pozorištu, 404.

14 „Neznatno skraćen tekst predavanja koje je Sartr održao 29. marta 1960. godine u velikom amfiteatru Sorbone. Prvi put objavljeno u knjizi Un théâtre de situations. "Ž.-P. SARTr, Drame. Tekstovi o pozorištu, 429.

15 „Sartrov razgovor s Kenetom Tajnanom prvi put je objavljen u londonskom The Observeru 18. i 25. juna 1961.“ $\check{Z}$.-P. SARTR, Drame. Tekstovi o pozorištu, 439.

16 Ž.-P. SARTr, „Stvoriti mitove“, 399.
} 
francuskih ${ }^{17} \mathrm{i}$ - neću pogrešiti ustvrdim li - evropskih pisaca, obeleženoj Drugim svetskim ratom. ${ }^{18}$ Poput generacije stvaralaca koja je stasavala kroz Prvi svetski rat, i pisci Sartrovog odnosno Desničinog naraštaja ratno će iskustvo, i iz njega proistekao odnos prema svetu i umetnosti, ispoljavati kroz različite modalitete. Činjenica je, međutim, da rat, sa moralnim dilemama i izopačenom ljudskošću, postaje rodno mesto problema koje oni u svojim delima tematizuju. ${ }^{19}$ Sartr i njegovi savremenici posebno ispituju „problem cilja i sredstava, problem opravdanosti nasilja i posledica određenog delanja, problem odnosa između pojedinca i zajednice, problem individualnog sukoba sa istorijskim datostima “. ${ }^{20}$ Desničine Ljestve Jakovljeve, koje ispituju ponašanje i odgovornost pojedinca, uz to i intelektualca, za ono što se dešava u ratom zahvaćenom svetu, postavljaju pred likove, ali i pred gledaoce / čitaoce pitanje može li, sme li čovek biti indiferentan i pasivan pred zločinom i institucionalizovanim nasiljem. Da li je strah od smrti dovoljno opravdanje za njegovo povlačenje i nesuprotstavljanje fašističkom, ili bilo kakvom drugom, pogromu? Iščezavaju li ljudskost i humanizam kad je glava u torbi? I da najdirektnije povežem ove tematsko-idejne zapitanosti sa likovima: Da li u trenutku monstruoznih egzekucija postoji razlika između prećutne saglasnosti i pasivnosti koju Jakov Pećina bira kao svoje vidljivo ja? Da li Jakov Pećina, i pored toga što ne odobrava nacizam i njegove metode, sa gestapovcem Huberom deli breme odgovornosti za zločine? Ovakva tematska usmerenost, i raspon duhovnih dilema koje izražava i predstavlja Vladan Desnica u Ljestvama Jakovljevim, posve se uklapaju u problematiku koju Sartr označava kao savremenu, ali i u njegovu zamisao teatra koji na scenu izvodi čoveka slobodnog „, granicama sopstvene situacije“, čoveka „koji hteo ili ne, pravi izbor za sve druge, kada ga pravi za sebe samog“. ${ }^{21}$

Šta je cilj teatra situacija i kakve zahteve on postavlja pred stvaraoca? Jedna od ključnih postavki proističe iz Sartrovog uverenja da „pozorište postoji tek kad se postigne zajedništvo svih gledalaca“, što praktično znači da situacije koje se predstavljaju moraju biti „toliko opšte da mogu biti zajedničke svima“. ${ }^{22}$ Težnja da se sasvim različiti ljudi koji sede u publici ${ }^{23}$ povežu i stope u celinu počiva na ideji da „bi pozorište trebalo da bude: jedan veliki kolektivni i religiozni fenomen “. ${ }^{24}$ Stoga i ne čudi što takvo pozorište mora biti moralno, odnosno što se kroz konfrontiranje prava, koja Sartr vidi kao čvorište sukobljavanja, ono

$17 \quad$ Isto, 398.

18 Vladan Desnica i Žan-Pol Sartr ne samo da su rođeni iste godine (1905) i preživeli ratnu golgotu, već rat i njegove posledice, zločini, moralna iskušenja i zastranjivanja nalaze značajno mesto u njihovom stvaralaštvu. Navešću kao primer dve Sartrove drame - Prljave ruke i Zatočenike iz Altone. Kad je o Desnici reč, takođe ću ostati pri dramskim delima, pa pored Ljestava Jakovljevih pomenuti nedovršeni komad Gadni mali gnom, koji je u piščevoj zaostavštini pronašao i objavio Dušan Marinković. Videti: Vladan DesnicA, „Gadni mali gnom“, Književna republika, 6/2008., br. 3-4, 3-21.

19 Sartr navodi da „umetničko delo, čak i kad nije političko, nastaje iz shvatanja svog vremena i mora biti u skladu sa svojim vremenom“. Up. Ž.-P. SARTr, „Razgovor sa Kenetom Tajnanom“, Drame. Tekstovi o pozorištu, 434.

20 Ž.-P. SARTr, „Za pozorište situacija“, Drame. Tekstovi o pozorištu, 390.

21 Ž.-P. SARTr, „Stvoriti mitove“, 400.

22 Ž.-P. SARTr, „Za pozorište situacija“, 390.

23 Ne mogu se oteti utisku da je Sartrovo ukazivanje na to kako u gledalištu „gojazan poslovni čovek sedi kraj kakvog trgovačkog putnika ili profesora, čovek sedi pokraj žene, i svako od njih ima sopstvene brige“ (Ž.-P. SARTR, „Stvoriti mitove“, 402) u stvari izvestan omaž Geteu, tačnije Predigri u pozorištu iz Fausta.

24 Ž.-P. SARTr, „Stvoriti mitove“, 402. 
bavi sukobima „sistema vrednosti, sukobi[ma] čovekovih moralnih i pojmovnih sistema“.25 Iako bi se moglo pretpostaviti da je u takvoj konstelaciji elemenata najvažniji karakter, Sartr, koji ne odbacuje sasvim psihološku dimenziju karaktera, ${ }^{26}$ ipak tvrdi da je presudna situacija, i to potkrepljuje prilično ubedljivim primerima:

Nisu bitne razlike u karakteru između jednog staljiniste i jednog trockiste; godine 1933. jedan antinacista i jedan SS nisu dolazili u sukob zbog razlika u karakterima; teškoće u međunarodnoj politici ne potiču od karaktera ljudi koji nama upravljaju; štrajkovi u Sjedinjenim Državama nisu prouzrokovani sukobima karaktera između industrijalaca i radnika. ${ }^{27}$

A univerzalne, opšteljudske situacije na koje se poziva, opredmećene kroz „velike mitove smrti, progonstva, ljubavi“ “ ${ }^{28}$ neophodno je prikazati u trenutku kulminacije. Taj trenutak, koji liku omogućava, primorava ga da izabere u novonastalim okolnostima, povoljnim, nepovoljnim, blagonaklonim ili pretećim, u isti mah je oličenje sistema vrednosti i aktuelnih prava koja junak brani, ali i ogledalo slobode kojom raspolaže. Delanje proisteklo iz slobode izbora u datoj situaciji jeste, prema Sartru, „nešto najuzbudljivije što pozorište može da prikaže“, jer je posredi „karakter u nastajanju, trenutak izbora, slobodna odluka koja angažuje moral i čitav jedan život“. ${ }^{29}$ Razlažući ovakvo viđenje teatra Sartr objašnjava da „čovek kog sticaj okolnosti neminovno vodi u propast nije kadar da nas gane. Nema veličine u njegovom padu do ako strada svojom krivicom. " ${ }^{30}$ Drugim rečima, krivica koja izvire iz slobode izbora, iz prava na koje se polaže pravo, koja ističe ličnu odgovornost, snažno deluje na gledaoca

(...) koji je istovremeno i običan čovek, i neko kome je data uloga moralnog sudije; on sudi o potezima i kaže: ovaj je u pravu, ovaj nije; a samo iznenađenje u pozorištu skoro uvek dolazi otud što se odjednom pokaže da i onaj za kog se mislilo da nije u pravu, ima, bar donekle, naravno, pravo. (...)

Pozorište tako postaje poput zatvorenog polja u koje ljudi dolaze da bi dokazali svoja prava. Potrebno je još i da nas ta prava zanimaju i stoga je nužno da to budu aktuelna prava... ${ }^{31}$

Prema Sartru, pravo je aktuelno ako je značajno i intrigantno u savremenom trenutku. Međutim, koliko god ukazivalo na nešto skorašnje, koliko god se odnosilo na autoru i gledaocima blizak i poznat istorijski i društveni kontekst, aktuelno pravo nosi u sebi dvostrukost, barem kad su posredi dela neupitne vrednosti, jer se u njemu susreću aktuelno i univerzalno. ${ }^{32}$ Ono što dodatno pojačava utisak, spaja pojedince u gledalištu i doprinosi

25 Isto, 401.

26 Sartrov odnos prema udelu psihologije u dramskom delu i teatru menjao se tokom godina. Dok 1946. tvrdi: „Mi ne odbacujemo psihologiju, što bi uostalom bilo besmisleno: mi je integrišemo u život “ (Ž.-P. SARTR, "Stvoriti mitove“, 401), četrnaest godina kasnije je izričit: „pozorištu nije potrebna psihologija. U pozorištu psihologija je samo gubljenje vremena. (...) A stvoriti pozorišni komad to upravo znači gurnuti ljude u poduhvat; psihologija nije potrebna.“ Ž.-P. SARTr, „Epsko i dramsko pozorište“, Drame. Tekstovi o pozorištu, 425.

27 Ž.-P. SARTR, „Stvoriti mitove“, 401.

28 Isto, 402.

29 Ž.-P. SARTR, „Za pozorište situacija“, 389.

30 Isto.

31 Žan-Pol SARTr, „Dramski stil“, Drame. Tekstovi o pozorištu, 395.

32 Naravno, aktuelnost prava je promenljiva kategorija jer se, shodno događanjima na jednom široko zasnovanom planu, univerzalno pravo zaodenuto individualizovanim okolnostima ciklično aktuelizuje. Stoga se reditelji i pozorišne kuće odlučuju da postave ili da ponovo pročitaju određena, a ne neka druga, dela u određenim društveno-istorijskim situacijama. 
prerastanju pozorišnog čina u kolektivni religiozni fenomen jeste alternativa koja se ukazuje junaku. Premda se sloboda ne zadobija spremnošću na umiranje, odnosno premda cena slobode nije smrt, pred junakom se, u vezi sa onim što bira da čini, kao jedna od dveju mogućnosti naglo otvaraju vrata iza kojih vreba smrt, jer „u smrt se ne ide korak po korak, čovek je odjednom suočen sa njom“. ${ }^{33}$ Ovakvim uvođenjem smrti - tragičnog ljudskog usuda kojem ni najprivilegovaniji ne mogu umaći, Sartr otvara prostor za dramsko promišljanje najbolnije čovekove zapitanosti, kako na idejnom planu tako i u pogledu dramaturške funkcionalnosti. Sveprožimajuća prisutnost smrti se u skladu s tim višestruko ispituje: i kroz činjenja koja izazivaju smrt ili trasiraju put do smrti (doslovna, moralna itd.), i kao direktna pojavnost (ubistvo, smrt na pozornici, na primer), i kao značajna dramaturška poluga koja pokreće ili usmerava radnju. Istina, Sartr „zaboravlja“ da prokomentariše neminovnost smrti, moguće zbog njene aksiomatske pozicije u ljudskom životu, pa se mudro usredsređuje na slobodu i čovekov angažman proistekao iz sudara sa okolnostima koje ne bira, ali spram kojih se mora postaviti, pre svega delanjem. Time se krug zatvara: delanje je uslovljeno pravom koje je autentični izraz onoga što je lik u situaciji sa kojom se nosi. Tako sagledavajući i predstavljajući čovekov položaj, pozorište situacija omogućava gledaocu da stekne uvide o sebi samom, o sopstvenim dilemama i iskušenjima, i to kroz potvrdu / osporavanje određenih prava „kao što su građanska prava, porodična prava, individualni i kolektivni moral, pravo da se ubije, pravo da se ljudima otkrije njihova ništavna sudbina, i tako redom". ${ }^{34}$

\section{LJESTVE JaKOVLJEVE I SaRtrovo POZORIŠTE SITUACIJA}

Po čemu su i u kojoj meri Ljestve Jakovljeve saobražene Sartrovom pozorištu situacija? Prvo, Desničina drama, po problematici kojom se bavi, ne pripada takozvanoj građanskoj drami, u čijem se tematskom okrilju razvija psihološka i naturalistička dramaturgija. Naime, Ljestve Jakovljeve u prvi plan postavljaju intrigantnu priču o čoveku koji, želeći da sačuva život po svaku cenu, kukavički relativizuje svoje moralno posrtanje, dok se ne suoči sa sopstvenim izobličenim licem i posledicama koje ono proizvodi. Otrežnjenje nastupa prekasno, te posledice problematičnog (ne)̌̌injenja postaju zamajac ishoda koji gledalac prividno neće videti na sceni. Kažem prividno, budući da se on u anticipirajućem snu protagoniste već odigrao pred publikom, donoseći Jakovu Pećini anagnorizam (anagnorisis). Stoga će ovaj tragički lik Desničinog komada, ničiji mrtvac i prividno živ čovek, pre spuštanja zavese shrvan, kao u ropcu, reći: „Strahota!... Sad čitava priča započinje iznova!..." ${ }^{35}$ Pošto je noćna mora mučnim doživljajem upozorila snevača da je nešto u njegovom životu duboko pogrešno, buđenje će postati prolog more na javi: lik je spoznao sopstveni položaj, učinjene pogreške i njihovu štetnu dalekosežnost. Ali povratka nema, sloboda da se donese

33 Ž.-P. SARTR, „Stvoriti mitove“, 403.

34 Isto, 401.

35 Vladan Desnica, Zimsko ljetovanje. Pjesme. Ljestve Jakovljeve (= Sabrana djela Vladana Desnice, knj. IV), Zagreb 1974., 333. 
odluka u dramatičnim okolnostima je iskorišćena, pravo na koje se profesor Pećina pozivao pokazalo je svoje naličje, a rečenica „Običan privatni čovjek nije dužan da bude heroj", 36 kojom je prao ruke uzmičući pred sopstvenom moralnom odgovornošću, i maskirao strah od smrti, preobrazila se u prvorazrednu demagošku frazu. Pravo koje brani Jakov Pećina, pravo da ostane neutralan, skrštenih ruku u momentu kad se svet raspolućuje nadvoje, razotkriva kukavicu i izdajnka skrivenog u čoveku. Jakovljevu uspaničenu malodušnost, čiji je simbolički vrhunac zastrašenost „fantomom nekakvog Biserka-Triserka “, ${ }^{37}$ još uočljivijom čini društveni status - profesor Pećina je uvaženi član društva, viđeni intelektualac. A ulog je za svakog pojedinca neprocenjivo velik - sopstveni život odnosno sopstvena smrt, čime se dodatno osnažuju pitanje morala i sukobljavanja prava: da li se boriti, aktivno se suprotstaviti neprijatelju, sa svešću da možeš biti mučen i ubijen, da možeš stradati zbog svog angažmana, ili živeti između juče i sutra, u svojevrsnoj neutralnosti koja bi trebalo da obezbedi i preživljavanje po svaku cenu uz - kako sam sebe ubeđuje protagonista Ljestava Jakovljevih - neokaljani obraz.

Situacija u koju Desnica postavlja svoje likove, davši im slobodu da biraju sopstveni identitet u sudaru s istorijskim neprilikama, priča je o čovekovoj odvažnosti i slabićstvu, o ličnoj odgovornosti pred sobom i drugima u vremenu kad se sve vrednosti jednog sveta raspadaju pred institucionalizovanim nasiljem. Drugim rečima, to je priča kojom se može podstaći jedinstvo u gledalištu, jer je posredi arhetipska situacija koja je toliko opšta da može biti zajednička svima. Vladan Desnica na to upućuje i znakovitim naslovom, kojim se, kao i postavljanjem biblijskog citata za moto dela, odnosno aludiranjem na biblijskog Jakova, uspostavlja daleko obuhvatniji značenjski i idejni kontekst drame u celini. Time se siže, zatim situacija koja zahteva da Jakov Pećina izabere kako će postupiti na osnovu prava koje brani, jednako kao i etičke implikacije njegovog ponašanja, povezuju s mitom na jednom dubljem, suštastvenom nivou, i postaju deo svevremene priče o čovekovom moralu, sistemu vrednosti, izdaji i krivici.

I Sartrova ideja da lik slobodno bira šta mu je činiti u određenoj situaciji, gradeći tako, kroz radnju, sopstveni identitet, pokazuje se kao princip delatan u Desničinoj drami. U „situaciji koja je poziv, koja hvata u mrežu i predlaže rešenja, likovima ostaje da odluče“. ${ }^{38}$ Petar Orljak, profesor, u vreme okupacije, represalija i egzekucija, talaca, likvidacija jataka i saslušanja u specijalnoj policiji - postaje aktivni zagovornik i potpora pokreta otpora i partizana. Njegova kći Dunja, maturantkinja, kao i njeni vršnjaci i drugovi Ognjen i Miško, nešto mlađi Zdravko, te Grga mlekar, od učenika na pragu zrelosti izrastaju u herojske figure. A Jakov Pećina, koji je u nekoj davnašnjoj ratnoj situaciji izabrao da bude na frontu u Galiciji, gde je i ranjen, od čega mu je ostalo ukočeno desno koleno, taj i takav Jakov u novoj ratnoj situaciji gradi potpuno nov identitet. Bivši ratnik i ugledni intelektualac motivisan je isključivo željom da ne nastrada, ne pogine slučajno, nehotice, ali i da ne dovede život u opasnost kao saradnik „rebelâ, čvrsto veruje da mu se ništa ne može prebaciti“ ${ }^{\text {“39 }}$ jer

\footnotetext{
36 Isto, 281.

37 Isto, 317.

38 Ž.-P. SARTR, „Za pozorište situacija“, 389.

39 V. Desnica, Ljestve Jakovljeve, 279.
} 


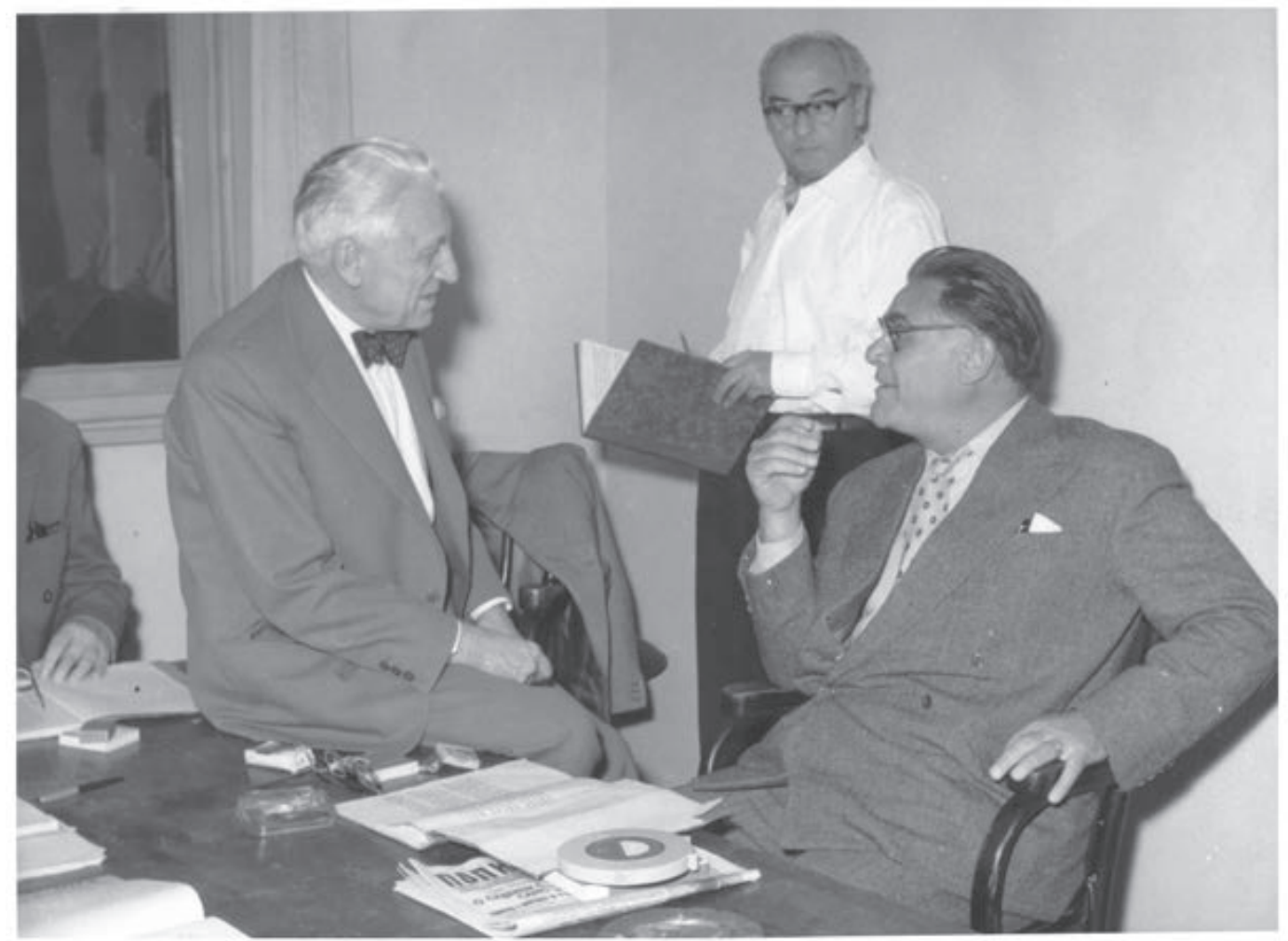

Sl. 2. Fotografija sa čitaćih proba Ljestava Jakovljevih 1960. godine: Tomislav Tanhofer, Viktor Starčić i Vladan Desnica

se „potpuno povukao, nikome ne ide, ništa ne piše“ ${ }^{40}$ Strah od smrti je toliki da on svom prijatelju, ali i oponentu Petru Orljaku iskreno kaže:

Kad se iznenada nađemo licem u lice s tim biti ili ne biti, tad opet rukne iz nas ona primarna zvijer! Padaju sva načela i osvjedočenja, i na njihovo mjesto stupa jedan jedini imperativ: spasiti glavu!... ${ }^{41}$

Jakov moralni kodeks kojim se rukovodi obrazlaže i rečima:

Taj sitni individualni životić, ta otrcana krpa mesa koju teglimo i po cijenu svega i svačega spasavamo, odjednom postaje vrhovno, jedino dobro. ${ }^{42}$

Njegovi postupci prema Veri, ali i oni sadržani u njegovom predikativnom snu, koji svedoče o nepojmljivom podlaštvu, nisu samo slika krajnje niskosti koju lik dotiče pre samospoznaje, nego su i izraz jednog poremećenog sistema vrednosti utabanog pravom koje Jakov Pećina predano brani, a to je pravo na odbranu sopstvenog života po svaku cenu. Gotovo da je tragikomično što, opredelivši se za takav stav, očekuje da ostane čistih ruku. Birajući

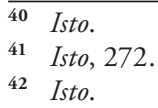


sebe takvog Jakov je odabrao i za druge - izdaće i Veru, i Orljakove, i mlade revolucionare. Taj novi Jakov zadobija i novo mesto među drugima. Ono se prepoznaje po oštrim jetkim kritikama i prebacivanjima koja mu upućuje Petar, po Huberovim mefistofelovskim marifetlucima i poigravanju, ali i po Dunjinom prezrivom distanciranju. Hrabra, neustrašiva borkinja za slobodu, ova devojka ne posustaje ni pred specijalnom policijom, ni pred izvesnošću smrti. U teskobnoj situaciji njena sloboda progovara kroz pravo na otpor nasilju. I zato Dunjini odgovori Jakovu, porodičnom prijatelju i nekadašnjem uzoru, odišu jedva prikrivenom hladnoćom.

U Ljestvama Jakovljevim je kroz još jedan lik - lik šturmfirera Josefa Hubera - i implicitno potvrđena Sartrova ideja da je situacija poziv. U tekstu je baš Jakovu Pećini dato da progovori o tome:

Čudno krivudaju životne putanje u današnjim poremećajima! Bez tih ratova i revolucija, moj bi Huber bio mirno zaplovio u akademsku karijeru. (...) Zakamufliran profesorskom bradom i očalama, iživljavao bi svoju perverziju u zatvorenim okvirima univerzitetskih programa i solidnog obiteljskog života. Ovako, prvi ga je rat srozao s akademskih visina u privatne činovnike, a drugi isturio iz privatnih činovnika u šturmfirere. ${ }^{43}$

Takođe, kroz reči koje izgovara Petar Orljak mogu se posmatrati i druga implicitna poetička poklapanja Desničine drame sa idejama Sartrove teorijske dramaturgije. Ljestve Jakovljeve se otvaraju dijalogom dvojice prijatelja koji se naročito bave pitanjem šta da se radi u ratnoj situciji. Kao zagovornici oprečnih sistema vrednosti i različitog vrednovanja moralnosti određenih postupaka, što na videlo izlazi u prolećnoj noći u okupiranom gradu, konfrontiraće se Petar Orljak, profesor i predstavnik onih koji se bore protiv okupatora, i Jakov Pećina, profesor i demagog, koji iz straha za goli život odbija da rečju i delom javno iskaže svoj stav. Jedno od ključnih pitanja koje će se ispoljiti u žaru diskusije jeste i pitanje slobode - okupacija i nasilje iziskuju da se bez odlaganja donesu odluke, ali i da se preduzmu određeni koraci. Petar Orljak pojam slobode doživljava u sartrovskom ključu, jer je izjednačava sa donošenjem odluke i delanjem u situaciji sa kojom se čovek suočava:

Uprav zato što svak posmatra stvar iz jedne subjektivne vizure, svak je nužno angažovan, bilo na jednoj ili na drugoj strani. I čovjek se, ni sam pravo ne znajući kako, odjednom nađe pred nekom tragičkom dilemom. ${ }^{44}$

Jakov Pećina, relativizujući objektivne okolnosti, govori o unutrašnjoj slobodi, što Petar kvalifikuje kao oslobođenost od svake moralne odgovornosti prema drugima. Pokazujući mu neodrživost relativizovanja kojem pribegava, Petar navodi:

Ali same prilike, događaji, postupci drugih, neodoljivo te povuku za sobom, dovedu te u situaciju kad ta tvoja odluka dođe u sukob s najosnovnijom ljudskom dužnošću, s najprirodnijim ljudskim osjećanjem. (...) Hoćeš li, da bi zaštitio sebe, popustiti presiji i posvjedočiti neistinu o svome kolegi, svome prijatelju? Nećeš? Već si se našao pred tragičkom dilemom, već si aktivno angažiran. ${ }^{45}$

$\begin{array}{ll}43 & \text { Isto, } 291 . \\ 44 & \text { Isto, } 281 . \\ 45 & \text { Isto, } 282 .\end{array}$ 


\section{ZAKLJUČAK}

Povest o odgovornosti pojedinca u dramatičnim istorijskim danima, koju Desnica kroz Ljestve Jakovljeve iznosi pred svoje savremenike, ali i pred sve one koji danas gledaju / slušaju / čitaju ${ }^{46}$ njegov komad, idući od pojedinačnog ka opštem, oživljava, u novom ruhu, mit o odgovornosti pojedinca u problematičnom i zahtevnom vremenu, progovarajući o kukavičluku, izdaji, malim i velikim ljudskim strahovima, ali i o odgovornosti, odvažnosti i idealizmu. Ovaj mit, sazdan na sukobljavanju oprečnih vrednosti, za koje se zalažu zagovornici različitih prava - Petar Orljak i njegova kći sa svojim drugovima, kao oličenje prava na otpor nasilju, naročito institucionalizovanom, naspram Jakova Pećine, koji brani pravo da spase glavu po svaku cenu, pravo da bude neutralan i neprimetan - provokativan je i savremen u svakom vremenu, a ne samo u ratnom, okupacionom, u koje Desnica postavlja svoje likove. Jer svako vreme ima svoje silnike, mnoga istorijska razdoblja i sistemi vlasti počivaju na nasilju i prinudi, pa je suočavanje gledaoca / slušaoca / čitaoca sa dramatičnim posledicama odluka proisteklih iz izbora koje pojedinac pravi prilika da se zagleda u sebe sama i zapita: $A$ šta bih, kako bih ja? ili možda Šta učinih? Drugačije rečeno, posredi je univerzalna egzistencijalna situacija u kojoj se, pre ili kasnije, nađe svaki čovek, budući da ličnu odgovornost i lični moral na probu stavljaju okolnosti čije je naličje smrt, neminovnost stradanja - sopstvena i drugih ljudi. Motivi zbog kojih se pojedinac ponaša na određeni način, naporedo sa njegovim postupcima, definišu pojedinčev identitet u situaciji kojoj je izložen, i pokazuju kuda ga vodi sloboda da izabere, da se opredeli između dve mogućnosti. Vladan Desnica se ovakvim udaljavanjem od realističko-naturalističko-psihološke drame, odnosno od uskih tematsko-sadržajnih i idejnih okosnica građanske drame, opredelio za svojevrsni tragički diskurs svojstven onome što je sredinom dvadesetog veka imenovano kao novatorski manir francuskih autora. Odnosno, Desnica se Ljestvama Jakovljevim na mapi dramaturških traganja, eksperimenata i ména, u prošlom veku, upisao među dramske pisce čije pozorišne komade odlikuju „žive rasprave među ličnostima koje sa strašću brane svoja individualna prava“, 47 čiji komadi svojim stilom „umesto da probude osećanje prisnosti, povećavaju distancu između dela i publike “ ${ }^{48}$ napose, čiji komadi o čoveku govore „sa ozbiljnošću, autoritetom i univerzalnošću tragedij ““.99 Sudbina koja sustiže likove „samo je naličje slobode“ ${ }^{50}$ a piscu i njegovom delu ,je jedino stalo do toga da ispita čovekov položaj u njegovoj sveukupnosti i da savremenom gledaocu pruži portret njega samog, sa svim njegovim problemima, nadanjima i borbama". ${ }^{11}$ Uvidi koje omogućava tematska, idejna i

\footnotetext{
46 Prema podacima koje sam dobila od Lade Martinac Kralj, dramaturškinje i urednice Radio drame na Hrvatskom radiju, Ljestve Jakovljeve su kao radio drama emitovane dva puta: premijerno 7. 5. 2011. u emisiji Radio scena na Prvom programu, a reprizno 14. 7. 2011. na Trećem programu Hrvatskog radija, u emisiji Radio drama. Režiju ovog izvođenja potpisuje Dejan Šorak, adaptaciju Lada Martinac Kralj, muzički ga je uredio Žarko Joksimović, ton majstor je bio Srđan Nogić, a glumili su: Franjo Kuhar, Vinko Kraljević, Ana Kraljević, Damir Šaban, Pjer Meničanin, Asja Jovanović, Andrej Dojkić i Sven Mađarević.

47 Ž.-P. SARTr, „Stvoriti mitove“, 403.

48 Isto, 403-404.

49 J. Hristić, „Filozof u pozorištu“, 115.

50 Ž.-P. SARTR, „Za pozorište situacija“, 389.

51 Ž.-P. SARTr, "Stvoriti mitove“, 402.
} 
dramaturška analiza Ljestava Jakovljevih, kao i sagledavanje eksplicitnih i implicitnih poetičkih poklapanja između ovog Desničinog komada i tekstova kojima je uobličena Sartrova teorijska dramaturgija, svedoče da se ne smeju zanemariti veze koje postoje između sartrovskog retoričkog pozorišta svesnih odluka i drame Vladana Desnice. Još preciznije, današnjem izučavaocu se Desničino dramsko delo pokazuje kao izrazito i suštinski utemeljeno u poetiku pozorišta situacija.

\section{$\cos$}

\section{Izvori i literatura}

Izvori

Vladan Desnica, Zimsko ljetovanje. Pjesme. Ljestve Jakovljeve (= Sabrana djela Vladana Desnice, knj. IV), Zagreb 1974.

Žan-Pol SARTr, Drame. Tekstovi o pozorišstu, Beograd 1981.

\section{Literatura}

И[ванка] Б[Ешевит], „Дестве Јаковљеве ВАадана Аеснице“, Политика (БеограА), br. 17017, 16. 2. 1961., 11.

Jadranka BRNČıć, „Problem etičkog angažmana u Desničinim Ljestvama Jakovljevim“, Intelektualci i rat 1939. - 1947. Zbornik radova s medunarodnog skupa Desničini susreti 2012. (ur. Drago Roksandić i Ivana Cvijović Javorina), sv. 1, Zagreb 2013., 41-51.

Vladan Desnica, „Gadni mali gnom“, Književna republika, 6/2008., br. 3-4, 3-21.

Ели Финци, „Интелектуанне распре“, Политика (БеограА), br. 17019, 18. 2. $1961 ., 10$.

Jovan Hristić, Studije o drami, Beograd 1986.

M[ilosav] M[ırković], „Ljestve Jakovljeve“, Mladost, 6/1961., br. 228, 7.

Helena Peričić, „Izdaja / krivnja / ideologija u Desničinoj drami Ljestve Jakovljeve“, Tekst, izvedba, odjek. Trinaest studija iz hrvatske i inozemne dramske književnosti, Zagreb 2008., 121-135.

Helena Peričić, „Jezik ideologije i ideologija jezika u Desničinoj drami Ljestve Jakovljeve“, Desničini susreti 2010. Zbornik radova (ur. Drago Roksandić i Ivana Cvijović Javorina), Zagreb 2011., 49-61.

Слободан Селенић, „ВАадан Аесница: Фестве Јаковьеве“, Борба (БеограА), br. 40, 18. 2. 1961., 7.

Vladimir Stamenković, „Sumnja u intelektualnu akciju“, Književne novine, 12/1961., br. 139, 7. 


\section{$\cos$}

\section{The DRAMATURGY OF LIBERTY AND DEATH, OR, ABOUT VLADAN DESNICA'S LJESTVE JAKOVLJEVE IN LIGHT OF SARTRE'S CONCEPT OF THE THEATER OF SITUATIONS}

In this paper, Desnica's play Ljestve Jakovljeve (Jacob's Ladder) is analyzed in light of the key tenets of the theater of situations, as defined and developed by Jean-Paul Sartre. The topic is approached comparatively and the appropriate methods of theoretical dramaturgy and the history of theater are used in the study. The play centers on an intellectual in wartime circumstances, one who faces the vital, universal problem of individual responsibility in uncertain times, inextricably linked to core values and attitudes towards liberty and death. It is those very issues that Desnica focuses on in the ideological, thematic and dramaturgical outline of his playwrighting debut, thus placing it within the framework of the genre which Sartre considers the contemporary revival of classical tragedy, since the hero's downfall is his own doing, a result of a clash with historical givens. While creating the character of Jakov Pećina, Desnica chooses to represent him as a work in progress and show the moment of choice, a freely made decision with repercussions for morality and an entire lifetime. Dramatic conflict in the play arises from the conflict of current rights related to everyday life: Petar Orljak, his daughter and their comrades are the embodiment of the right to oppose violence, particularly structural violence, whereas Jakov Pećina, who defends his right to survive no matter what, embodies the right to be neutral and inconspicuous at a time of persecution. Desnica's play, thus, going from the individual to the general, revives the myth of individual guilt and responsibility in complicated historical circumstances in a new form. The permanence of this myth is underscored by the pointed title and the connection with the biblical figure of Jacob.The insights provided by the thematic, conceptual and dramaturgical analysis of Ljestve Jakovljeve, as well as the overview of explicit and implicit ways in which Desnica's play corresponds to the texts which define Sartre's theoretical dramaturgy, especially with regards to understanding and addressing the themes of freedom and death, clearly demonstrate that the connections between Sartre's rhetorical theater of conscious decisions and this play by Vladan Desnica should not be overlooked. More precisely, although neither Desnica himself nor his contemporaries read the play in that light, to a contemporary scholar, the play seems distinctly and fundamentally based in the poetics of the theatre of situations, comparable to the innovative manner typical of French authors.

Key words: Ljestve Jakovljeve (Jacob's Ladder), the theater of situations, freedom, death, the conflict of rights, choice, myth 